\title{
Comparison of Cooling Parameters of R134a and R290/R600a
}

\author{
D.O. Ariyo, M.A. Azeez and T.O. Woli \\ Department of Mechanical Engineering, Federal Polytechnic, Offa, Kwara State, Nigeria
}

\begin{abstract}
Cooling capacities and other parameters were determined for a refrigeration cycle operating between temperature limits of $-25^{\circ} \mathrm{C}$ (evaporator temperature) and $42^{\circ} \mathrm{C}$ (condenser temperature). The refrigerants used in the refrigeration cycle analysis were R134a and R290/R600a. Compressor capacity of $125 \mathrm{~W}$, degree of subcooling of $9 \mathrm{~K}$ and degree of superheating of $15 \mathrm{~K}$ were maintained for refrigeration cycles using R134a and a binary mixture of R290/R600a (50\% each by mass). Parameters such as refrigerating capacity, mass flow rate, compression work, condenser capacity and Coefficient Of Performance (COP) were computed for each refrigeration cycle. Flow rate of R134a is higher than that of R290/R600a which indicates its low evaporative specific heat. The cooling capacity of R134a $(376.41 \mathrm{~W})$ is higher than that of R290/R600a $(338.11 \mathrm{~W})$. COP of the cycle using R134a is 3.01 which is higher than that of R290/R600a. Suction and discharge pressures of the two refrigerants are fairly close. The analysis showed that cooling capacities of the two refrigerants are close enough and are therefore proposed as substitutes in existing R12 refrigeration systems.
\end{abstract}

Keywords: Refrigeration Cycle, R134a, R290/R600a, Cooling Capacities, Binary Refrigerants

\section{Introduction}

Refrigerants are working fluids in refrigeration systems. They absorb heat through evaporation and reject it through condensation. These phase changes occur both in vapour absorption and vapour compression refrigeration systems but not in systems operating on a gas cycle using fluids such as air (ASHRAE Fundamentals, 2013).

Refrigerant selection involves compromises between conflicting thermophysical properties. A refrigerant must satisfy many requirements some of which may not relate to its ability to transfer heat. Some of these requirements include chemical stability, safety issues, toxicity, cost, availability and compatibility with compressor oil and equipment materials. Efficiency of a theoretical vapour compression refrigeration cycle is maximized by refrigerants with low vapour heat capacity (ASHRAE Refrigeration, 2014; Arora, 2004)

Hydrofluorocarbon, (HFC) refrigerants contain no chlorine atom, therefore their ODP is zero. Refrigerant 134a of the fluoroethane series can be used as a direct replacement for R12, although service procedure has to be followed to retrofit existing R12 systems to R134a. For example mineral oils used as lubricants in R12 systems are not compatible with R134a. Instead relatively hygroscopic polyolester oils are used in R134a compressors.

Hydrocarbons such as propane (R290), n-butane (R600), Isobutane (R600a) and R290/R600a (50\% each by mass) are being used as refrigerants. They have zero Ozone Depletion Potential (ODP) and low Global Warming Potential (GWP), however they are highly inflammable which may constitute an obstacle to their widespread use as refrigerants especially for commercial and industrial applications. In household refrigeration and air-conditioning systems, quantities of hydrocarbon refrigerants that will be charged are very small compared with quantities of R12 charge for the same systems. Hydrocarbon refrigerants are compatible with mineral oils used in R12 systems (ASHRAE Refrigeration, 2014; ASHRAE Fundamentals, 2013).

\section{Choice of Operating Temperatures}

\section{Analysis}

To ensure effective heat transfer, design parameters are as follows: The refrigerator is designed for ambient (room) temperature of $32^{\circ} \mathrm{C}$ and refrigerated space temperature of $-15^{\circ} \mathrm{C}$. R134a and a binary mixture of R290/R600a (50\% each by mass) are considered as suitable alternatives to R12. Some old household refrigerating systems still run on R12, but, if leak occurs, these systems are expected to be retrofitted to R134a or R290/R600a. For domestic refrigeration systems running on R12, subcooling of liquid refrigerant by 9k corresponds to $15 \mathrm{~K}$ superheat of refrigerant vapour (Prasad, 2005; Dossat, 2004) hence these values were used in the analysis.

In order to achieve a reasonable heat transfer rate, a temperature difference of 5 to $10^{\circ} \mathrm{C}$ is expected to be maintained between the refrigerant and the medium for heat transfer (Nag, 2005). Figure 1 shows selection of operating temperatures. In this paper, a temperature difference of $10^{\circ} \mathrm{C}$ was maintained for evaporator and condenser respectively. For example, if the space is to be maintained at $-15^{\circ} \mathrm{C}$, the refrigerant will evaporate at - 
$25^{\circ} \mathrm{C}$. In operation, the space temperature is maintained at $-15^{\circ} \mathrm{C}$ and all the sensible heat coming into the space is transferred to the refrigerant and converted to latent heat of evaporation of the refrigerant. This conversion takes place at $-25^{\circ} \mathrm{C}$. With this temperature, corresponding saturation pressures of the two refrigerants are above atmospheric pressure so as to prevent ingress of air into the refrigeration system.

Room temperature of $32^{\circ} \mathrm{C}$ was chosen after several measurements in the four warmest months of the year (February, March, April, and May) (Ariyo, 1997). With this temperature, and temperature difference of $10^{\circ} \mathrm{C}$, condenser temperature is $42^{\circ} \mathrm{C}$. Having selected condenser temperature of $42^{\circ} \mathrm{C}$, evaporator temperature of $-25^{\circ} \mathrm{C}$, degree of subcooling of $9 \mathrm{~K}$ and degree of superheating of $15 \mathrm{~K}$, analysis of refrigeration cycles for R134a and R290/R600a was carried out based on the t-s and p-h diagrams in figures 2 and 3.

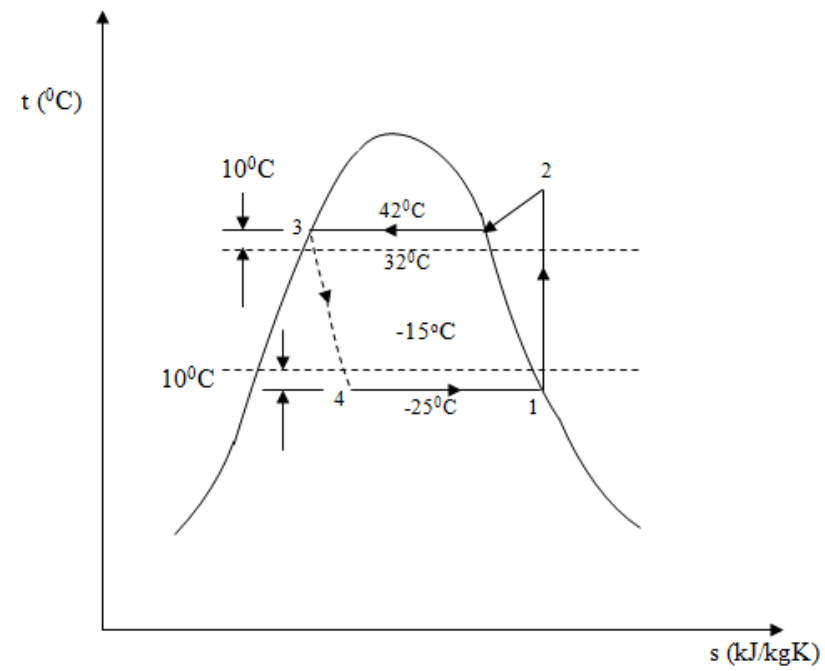

Fig. 1 Selection of Operating Temperatures

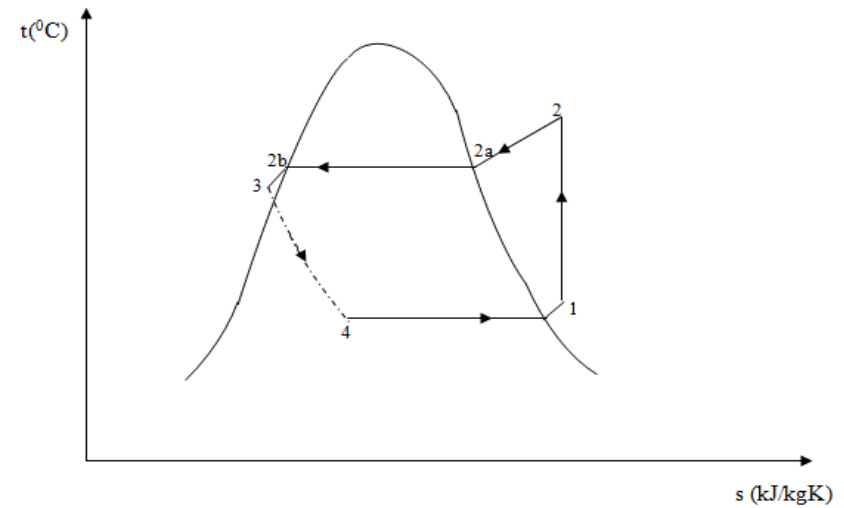

Fig. 2 t-s Diagram for the Theoretical Analysis

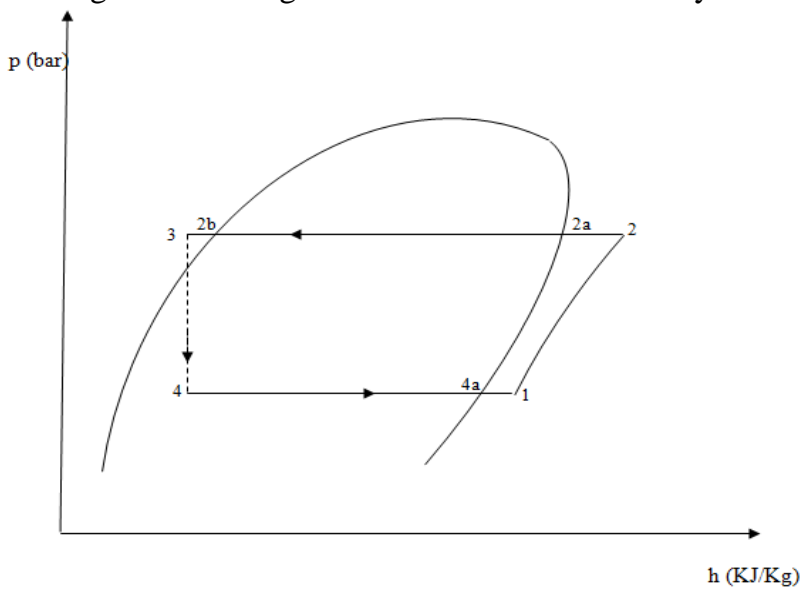

Fig. 3 p-h Diagram for the Theoretical Analysis 


\section{Results}

From first law of thermodynamic, steady flow energy equation (SFEE) is stated thus:

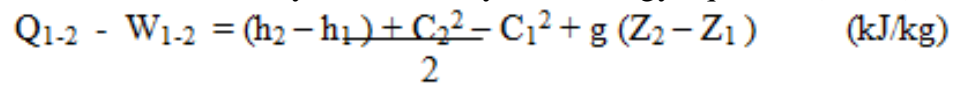

(Nag, 2005)

where

$\mathrm{Q}_{1-2}=$ heat transfer

$\mathrm{W}_{1-2}=$ work transfer

$\mathrm{C}_{1}, \mathrm{C}_{2}=$ velocity at states 1 and 2

$\mathrm{Z}_{1}, \mathrm{Z}_{2}=$ elevations at states 1 and 2

$\mathrm{g}=$ acceleration due to gravity.

For the four major refrigeration system components (compressor, condenser, throttle valve, evaporator) the kinetic energy term $\left(\mathrm{C}_{2}{ }^{2}-\mathrm{C}_{1}{ }^{2}\right) / 2$ and potential energy term $\mathrm{g}\left(\mathrm{Z}_{1}, \mathrm{Z}_{2}\right)$ are small compared with other terms in the equation therefore they are neglected. The equation reduces to

$$
\mathrm{Q}-\mathrm{W}=\Delta \mathrm{h}
$$

Equation (2) was applied to each component of the refrigeration system to arrive at the following equations that could also be derived from the $\mathrm{p}$-h chart.

\section{Compressor}

$$
-\mathrm{W}_{1-2}=\mathrm{h}_{2}-\mathrm{h}_{1}
$$

\section{Condenser}

$$
-\mathrm{Q}_{2-3}=\mathrm{h}_{2}-\mathrm{h}_{3}
$$

\section{Throttle Valve}

$$
\mathrm{h}_{3}=\mathrm{h}_{4}
$$

\section{Evaporator}

$$
\mathrm{Q}_{4-1}=\mathrm{h}_{1} \cdot \mathrm{h}_{4}
$$

Coefficient of Performance, $\mathrm{COP}=$ Refrigerating effect

/Compression work

$(\mathrm{kJ} / \mathrm{kg})$

Mass flow rate, $m=$ Refrigerating capacity/ Refrigerating effect

$(\mathrm{kg} / \mathrm{s})$

Refrigerant tables were used to pick enthalpy values for the computations. The results of the analysis are shown in Table1. Ozone depletion potentials and global warming potentials of the two refrigerants are shown in Table2.

Table 1 Performance Data of R134a and R290/R600a




Table 1 (Cont'd)

\begin{tabular}{|c|c|c|c|c|c|c|c|}
\hline Refrigerant & $\begin{array}{c}\text { Compression } \\
\text { Work } \\
(\mathrm{kJ} / \mathrm{kg})\end{array}$ & $\begin{array}{l}\text { Refriger-ating } \\
\text { or } \\
\text { Cooling } \\
\text { Capacity } \\
\text { (W) }\end{array}$ & $\begin{array}{c}\text { Mass flow } \\
\text { rate } \\
(\mathrm{kg} / \mathrm{s})\end{array}$ & $\begin{array}{l}\text { Coefficient } \\
\text { Of } \\
\text { Performance } \\
\text { (COP) }\end{array}$ & $\begin{array}{l}\text { Refrigerating } \\
\text { Effect } \\
\quad(\mathrm{kJ} / \mathrm{kg})\end{array}$ & $\begin{array}{l}\text { Condenser } \\
\text { Capacity } \\
\text { (W) }\end{array}$ & $\begin{array}{c}\text { Refrigerating } \\
\text { Efficiency\% } \\
\mathrm{COP}_{\text {actual }} / \\
\mathrm{COP}_{\text {Carnot }}\end{array}$ \\
\hline $\mathrm{R} 134 \mathrm{a}$ & 51.96 & 376.41 & 0.00240560 & 3.01 & 156.47 & 501.41 & 81.35 \\
\hline R290/R600a & 99.67 & 338.11 & 0.00125411 & 2.71 & 269.63 & 463.11 & 73.24 \\
\hline
\end{tabular}

Table 2 Ozone Depletion Potentials and Global Warming Potentials of the Refrigerants (ASHRAE, Refrigeration, 2014)

\begin{tabular}{llll}
\hline Refrigerant & $\begin{array}{l}\text { Compatible } \\
\text { Lubricant }\end{array}$ & ODP & GWP $_{100}$ Flammable
\end{tabular}

\begin{tabular}{lcccc}
\hline R134a & Polyolester (POE) & 0 & 1300 & No \\
R290/R600a & Mineral Oil (MO) & 0 & 3 & Yes
\end{tabular}

$50 \% 150 \%$

(by mass)

\section{Discussion Of Results}

The refrigeration system was designed to run on R134a and R290/R600a respectively and the performance of each of these refrigerants compared. At the operating temperatures considered, COP of R134a is better than R290/R600a. According to the results, mass flow rate of R134a is higher because its evaporation specific heat is lower. Although compressor size was fixed at $125 \mathrm{~W}$ for the two refrigerants, refrigerating capacities for the refrigerants are different with R134a refrigeration cycle having a higher COP of 3.01.

The refrigerating capacities of the two refrigerants with the same compressor capacity of $125 \mathrm{~W}$ are fairly close. Refrigerating capacity of R134a is higher than that of R290/R600a by 38.3W. Similarly COP of $\mathrm{R} 134 \mathrm{a}$ is higher than that of R290/600a. PolyOlEster(POE) oil is compatible with both refrigerants.

Table 2 shows ozone depletion potentials and global warming potentials of the two refrigerants. Ozone depletion potentials for both refrigerants are equal (zero) while the global warming potential of R290/ R600a is lower than that of R134a; hence it is more environmentally friendly than R134a. Hydrocarbon refrigerants have flammability problem.

The quantity of refrigerant charge of R134a for a given refrigeration system is higher than that of R290/R600a. This is due to high latent heat of vaporization of R290/R600a and hence its low mass flow rate (Arora, 2005).

\section{Conclusions}

Hydrocarbon refrigerants are available in the market; hence their use should be encouraged in refrigeration and air-conditioning equipment. Service procedure needs to be developed for safety because hydrocarbon refrigerants are highly inflammable.

From the results of this analysis, performance data of R134a and R290/R600a are good enough for the refrigerants to be used interchangeably; therefore they are recommended as alternative refrigerants in the manufacturing of new refrigeration and air-conditioning equipment and as substitutes to ozone-depleting refrigerants such as R12 and R22 in existing refrigeration and air-conditioning systems.

\section{References}

[1]. Ariyo, D.O. (1997). Models for ambient dry bulb temperature and relative humidity statistics related to building cooling loads for Ilorin and Ikeja. M. Eng. project report, Department of Mechanical Engineering, University of Ilorin.

[2]. Arora, C.P. (2004). Refrigeration and air-conditioning. $2^{\text {nd }}$ Edition. Tata McGraw-Hill publishing company limited. New Delhi.

[3]. ASHRAE (2014). Handbook of Refrigeration. S.I. Edition. American Society of Heating, Refrigerating and Air-Conditioning Engineers. Atlanta, G.A.

[4]. ASHRAE (2013). Handbook of Fundamentals. S.I. Edition. American Society of Heating, Refrigerating and Air-Conditioning Engineers. Atlanta, G.A.

[5]. Dossat, R.J. (2004). Principles of refrigeration. $4^{\text {th }}$ Edition. Pearson education (Singapore) Pte. Ltd, Indian Branch, Patparganj, Delhi.

[6]. Nag, P.K. (2005). Engineering Thermodynamics. $3^{\text {rd }}$ Edition. Tata McGraw-Hill publishing company limited. New Delhi.

[7]. Prasad, M. (2005). Refrigeration and air-conditioning. $2^{\text {nd }}$ Edition. New Age international (P) Limited. New Delhi. 